\title{
The grass family (Poaceae) in Coahuila, Mexico: DIVERSITY AND DISTRIBUTION
}

\author{
Jesús Valdés-Reyna ${ }^{1,3}$, José Luis Villaseñor², Juan A. Encina-Domínguez and EnRique Ortiz² \\ 'Departamento de Botánica, Universidad Autónoma Agraria Antonio Narro, Saltillo, Coahuila, Mexico \\ ${ }^{2}$ Departamento de Botánica, Instituto de Biología, Universidad Nacional Autónoma de México, México, D.F., Mexico \\ ${ }^{3}$ Author for correspondence: jvaldes.reyna@gmail.com
}

\begin{abstract}
We analyzed the species richness of the grass family (Poaceae) in the state of Coahuila, Mexico, evaluating data from herbarium specimens. The evaluation was made by dividing the state into a grid of $20^{\prime} \times 20^{\prime}$ squares (latitude $\times$ longitude), the objective was to identify areas of high species diversity. The herbaria revision documented 319 species of grasses, distributed in eight subfamilies, 19 tribes, and 97 genera. The genera with the highest number of species are Muhlenbergia (32 species), Bouteloua (21), and Eragrostis (18). Seven species are endemic to Northeastern Mexico (Bromus densus, Bouteloua eriostachya, B. johnstonii, Calamagrostis coahuilensis, Festuca coahuilana, F. valdesii, and Poa wendtii) and, 58 species, plus one subspecies and one variety are rare. Because arid areas cover a larger portion of the state, the subfamily Chloridoideae is dominant with 125 species. The subfamily Panicoideae has a record of 87 species and is mainly present in humid regions, while the Pooideae is abundant in the mountain regions of southeast and northwest, and includes 86 species. We evaluated the species richness for each grid square and propose some of these as important areas to carry out future conservation projects.
\end{abstract}

Keywords: conservation, endemism, grasses, species richness.

Resumen: Se analiza la riqueza de la familia de las gramíneas (Poaceae) en el estado de Coahuila, México, para lo cual se evalúan datos de los ejemplares de herbario recolectados, identificados y georreferenciados, provenientes de dicha región. Utilizando una división de la región en cuadros de $20^{\prime} \times 20^{\prime}$ (latitud $\times$ longitud), el objetivo fue identificar los sitios de alta diversidad para la familia. La región tiene documentadas, con ejemplares de herbario, 319 especies de Poaceae distribuidas en ocho subfamilias, 19 tribus y 97 géneros. Los géneros que tienen mayor número de especies son Muhlenbergia (32 especies), Bouteloua (21) y Eragrostis (18). Siete especies son endémicas del estado: Bouteloua eriostachya, B. johnstonii, Bromus densus, Calamagrostis coahuilensis, Festuca coahuilana, F. valdesii y Poa wendtii. Se consideran como gramíneas raras a 58 especies, una variedad y una subespecie. Debido a que en el estado las zonas áridas ocupan una mayor superficie, domina la subfamilia Chloridoideae, la cual posee 125 especies. Los miembros de la subfamilia Panicoideae se presentan en las zonas húmedas con 87 especies, mientras que las Pooideae son abundantes en las zonas montañosas del sureste y noroeste del estado, donde se presentan 86 especies. Se evalúa la riqueza por cuadro y se proponen algunos como importantes para llevar a cabo futuras estrategias de conservación con base en los patrones de riqueza encontrados.

Palabras clave: conservación, endemismo, gramíneas, riqueza de especies.

$S^{n}$ tudies on biodiversity at different scales (continent, country, national parks, or natural protected areas) constitute the basis for conservation and for establishing plans for proper management of natural resources (Smith and Wolfson, 2004; Klopper et al., 2007; Finot et al., 2009). Mexico is an important center of biodiversity clustering and endemism (hotspot), compared with other political entities of the World (Mittermeier, 1988; Villaseñor, 2003; Villaseñor and Ortiz, 2012). Floristic inventories are revealing regions with high plant diversity; however, many states of Mexico have not documented their plant richness and it is difficult to estimate the true richness they harbor; some states have degraded so much their landscape that it is difficult to determine the biodiversity because a high rate of the species are attributed to anthropogenic disturbance (Villaseñor and Ortiz, 2012).

Chorological studies of Mexican Poaceae (Valdés and Cabral, 1993) identified regions of high species diversity for the subfamilies Chloridoideae, Pooideae, and Panicoideae. They indicate centers of endemism and mention 272 endemic species, mostly belonging to the subfamily Chloridoi- 


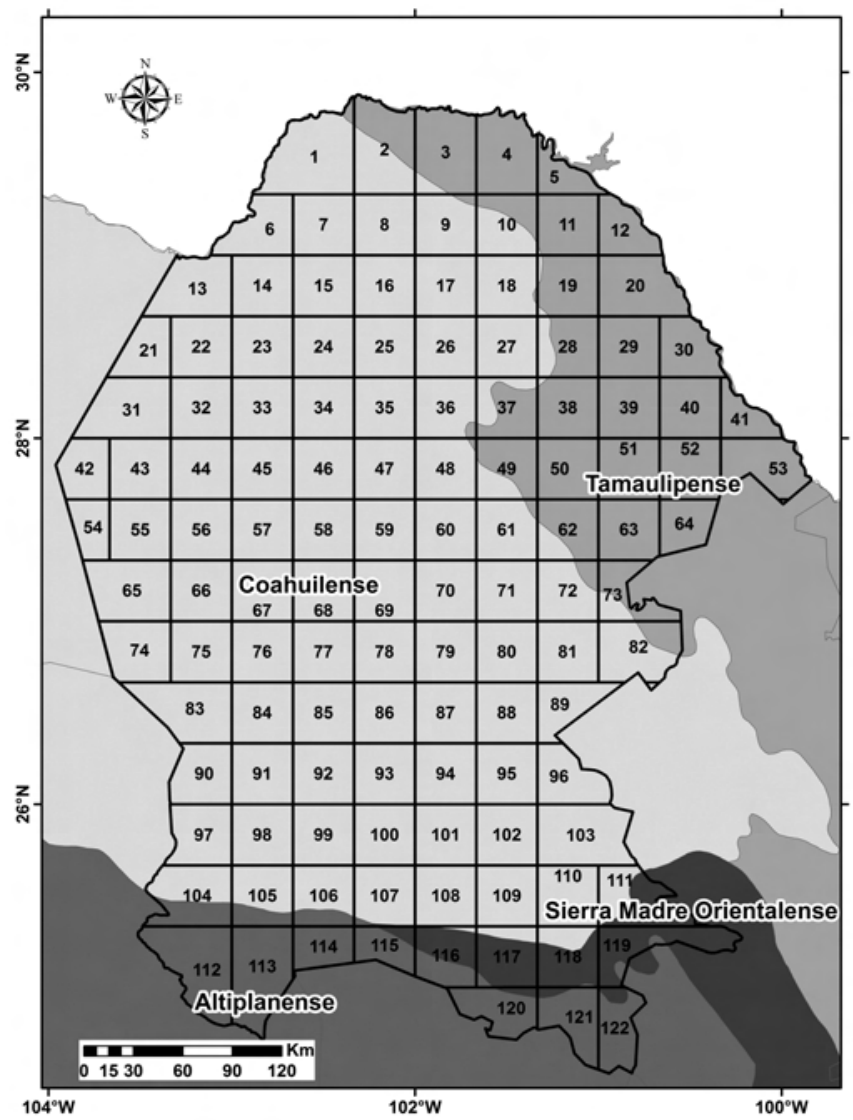

Figure 1. The morphotectonic provinces occurring in Coahuila.

deae (73 species). For Mexico, Valdés and Dávila (1995), and Dávila et al. (2006) list 204 genera, 1,182 species, and 207 subspecific categories; 1,119 are native, 278 are endemic to Mexico, and 159 are introduced, several of them known only under cultivation.

The state of Coahuila, located in northeastern Mexico includes wide arid and semi-arid regions, as well as several mountain and subtropical ones, harboring a rich grasses flora. The state is divided into two important eco-regions or diversification centers for species of arid zones, the Chihuahuan desert and the Tamaulipan desert, the figure 1 shows the morphotectonic provinces occurring in Coahuila. This study emerges from the necessity to update the checklist of the grasses in the state and determine localities that have high species richness. The main objective of this study was to determine patterns of species richness and estimate areas of high species diversity for the grasses of Coahuila.

\section{Materials and methods}

We generated a database for the known grass species in Coahuila. The data base contains 3,250 records collected along the state's political territory (Valdés, 1977; Valdés and Dávila, 1998). Specimens reviewed are registered in several herbaria, both in Mexico and foreign places (ANSM,
ARIZ, CIIDIR-DURANGO, COCA, CHAPA, ENCB, GH, MEXU, MICH, MO, NMCR, TAES, TEX, UAT, US, and WIS). Their study allowed us to verify their occurrences in the state. Also we reviewed the literature recently published on grass systematics, which includes nomenclatural changes for some genera and species distributed in the state of Coahuila (Bell et al., 2012; Peterson et al., 2012; Snow et al., 2013; Peterson et al., 2014; Saarela et al., 2014).

The information from collecting locations was employed to georeference specimens and then, to spatially validate latitude and longitude coordinates using the geographical information system software ArcMap 10 (ESRI, 2010).

We carried out a pattern diversity analysis dividing Coahuila into a grid squares network. The size of the grid squares or cells defined, followed recommendations of the International Union for Nature Conservation (IUCN, 2001) for estimating Areas of Occupancy (AOO). This agency suggests that in order to determine the AOO of a species, grid square size should be $10 \%$ of the distance between the two more distant gathering locations known for the species. In our analysis, AOO for each species was estimated by using a GIS extension for ArcView (Moat, 2007). The AOO median

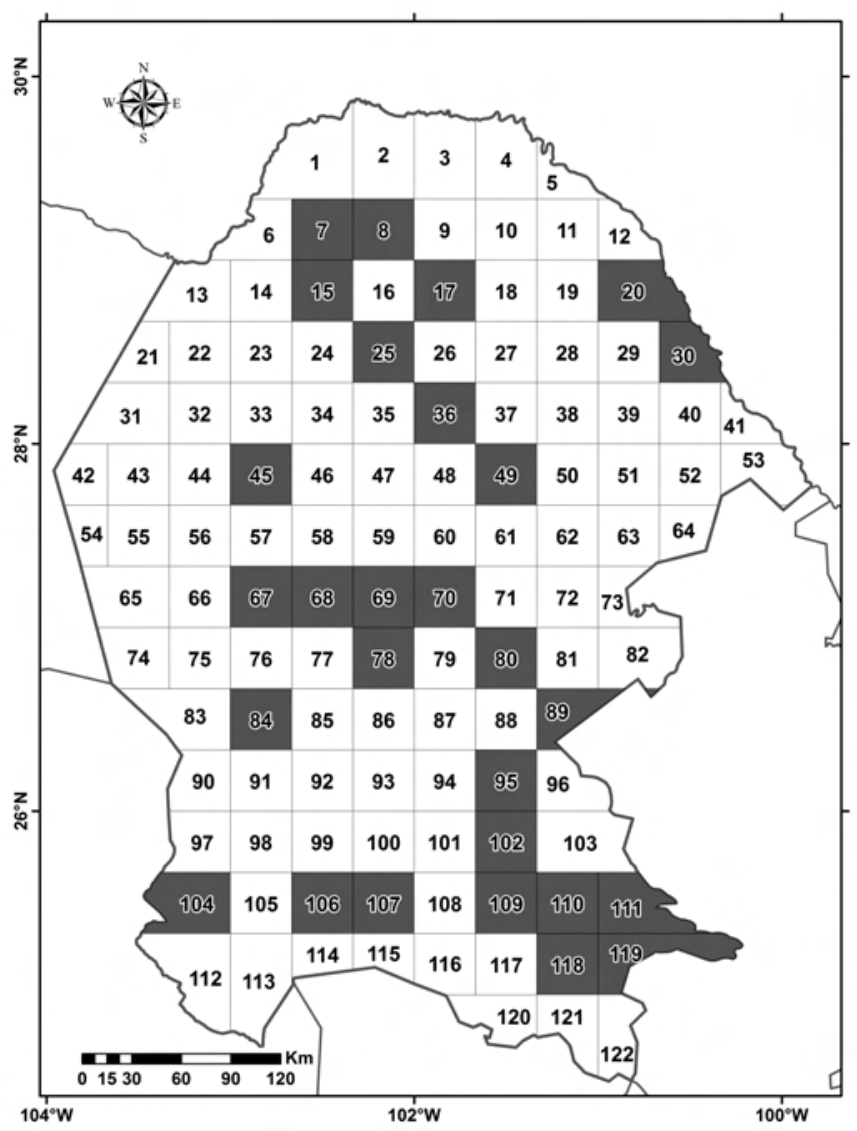

Figure 2. State of Coahuila divided in 122 grid squares 20' (latitude and longitude size). Shaded grid squares are considered irreplaceable for conservation purposes since they contain exclusive species. 
values of all estimates was obtained and used to determine cell size and this was applied to all species (Suárez-Mota and Villaseñor, 2011). The median obtained for cell size was $34.5 \mathrm{~km}$ per side, which is close to 20 arc minutes latitude and longitude. An edge effect resulted in cells of lesser size; therefore, those with a surface less than $50 \%$ of a full cell size were fused with a neighbor cell. In this way, the state of Coahuila was divided into 122 grid squares (Figure 2). This grid square system allowed us to determine the species richness for each cell by intersecting with the GIS the collecting locations from all the state's political surface.

Species accumulation curve. The species accumulation curves, because they consider rarity or abundance, are important emerging tools for estimating floristic richness from a place or region (Koellner et al., 2004). To evaluate how exhaustive the Poaceae inventory was in the herbaria studied, we obtained a species accumulation curve by using EstimateS version 8.2.0 software (Colwell and Coddington, 1994; Colwell, 2009). As a measure of the collecting effort, we considered the 20 arc minute cell size and we calculated the estimated richness using a parametric coefficient based on Clench's function (Jiménez-Valverde and Hortal, 2003) using Statistica version 10 software (StatSoft Inc., 2011). This function is now widely used to estimate the accumulation curves of the expected floristic richness. Soberón and Llorente (1993) explain with details Clench's function and discuss its usefulness and limitations in biological inventories.

Priority sites for conservation of Poaceae of Coahuila. Once we obtained the species geographical distribution by cell, we identified those with high species richness. Among them, those with exclusive species; i.e. species recorded only in this grid square. Such cells were considered as irreplaceable sites, if we want to carry out efficient conservation strategies of known species.

Species richness by cells helped us carry out a complementary heuristic analysis (Villaseñor et al., 2003) by ranking the cells in which the state was divided. Thus, we were

Table 1. Number of grass subfamilies, tribes, genera, and species recorded in Coahuila.

\begin{tabular}{lccc}
\hline Subfamily & Tribe & Genera & Species \\
\hline Bambusoideae & 2 & 2 & 2 \\
Ehrhartoideae & 1 & 1 & 2 \\
Pooideae & 7 & 36 & 86 \\
Panicoideae & 3 & 27 & 88 \\
Danthonioideae & 1 & 2 & 2 \\
Arundinoideae & 1 & 2 & 2 \\
Aristidoideae & 1 & 1 & 12 \\
Chloridoideae & 3 & 26 & 125 \\
Total & 19 & 97 & 319 \\
\hline
\end{tabular}

able to identify priority sites for conservation. In this work, endemism was not considered, only total species richness. Therefore, the complementary method (Villaseñor et al., 2003) was modified to not account ties in the number of endemic species (step 3 of algorithm), going directly to step 4 ("in case of a tie, the cell closest to one already selected will be selected"). If ties persisted, the cell with higher species richness was selected.

\section{Results}

To date, 319 species of Poaceae were recorded in Coahuila, all of them based on a herbarium specimen. The species are distributed in eight subfamilies, 19 tribes, and 97 genera (Table 1). Subfamily Chloridoideae, primarily distributed in arid zones, includes 125 species. Subfamily Panicoideae, usually found in more humid environments, includes 87 species, and Pooideae, found primarily in mountain temperate regions, includes 86 species. The other subfamilies include fewer species: Aristidoideae (12 spp.); Arundinoideae (2 spp.), Bambusoideae (2 spp.), Danthonioideae (2 spp.), and Ehrhartoideae ( 2 spp.). In Coahuila there are 253 native species and 65 naturalized or introduced species from Europe, Eurasia, Africa, and South America (Table 2). The genera with the most species are: Muhlenbergia (32), Bouteloua (21), Eragrostis (18), Sporobolus (13), Aristida (12), Setaria (11), and Panicum (11). In addition, 58 species are considered rare because their distribution is known only from one or just a few localities, and seven of these are endemic to the state: Bouteloua eriostachya, B. johnstonii, Bromus densus, Calamagrostis coahuilensis, Festuca coahuilana, F. valdesii, and Poa wendtii.

Poaceae richness does not distribute homogeneously in Coahuila. Figure 2 shows the state divided in 122 grid squares 20' $\times 20$ ' latitude and longitude (about $1,133 \mathrm{~km}^{2}$ ), and grasses were only found in 99 (Figure 3). Our results indicate $81 \%$ of the area is inequitably sampled, because 51 of the grid squares scored from 1 to 9 species, whereas 19 scored between 10 to 22 species, 17 scored between 23 and 38 species and only 12 scored more than 39 species.

The species accumulation curve (Figure 4) shows the number of species collected as a function of sampling effort in the grid squares. The curve reveals a confident, although incomplete inventory. The estimated species richness when the asymptote is reached $\left[y=16.13236 x(1+0.040668)^{-1}\right]$ suggests the inventory will be completed with 396 species. Therefore, it still remains to add about 73 additional species to the state richness ( $80.5 \%$ completeness).

Most species (96) restrict their distribution to a single grid square; 58 additional species are known from two squares. In general, $75.7 \%$ of total richness is known from no more than five squares and only eight species $(2.6 \%)$ are recorded from 15 or more squares. The widespread species are: Aristida adscensionis, A. purpurea, Bouteloua curtipendula, 


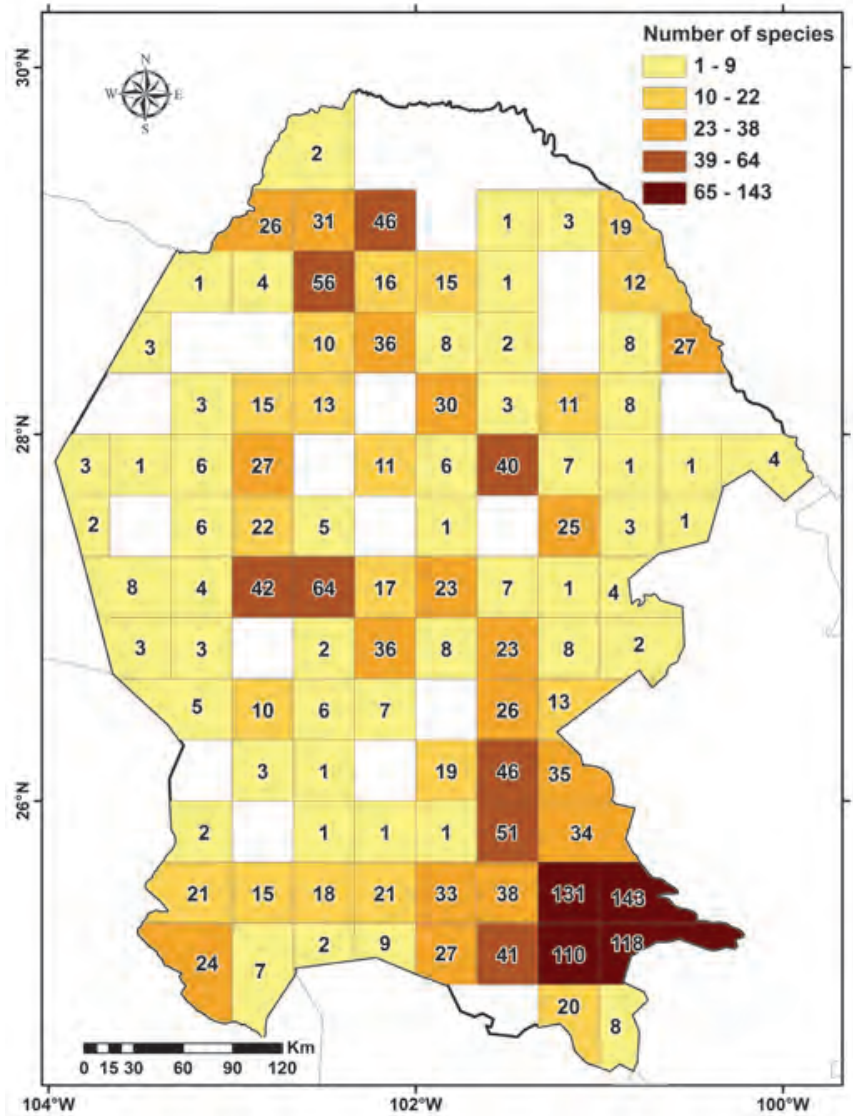

Figure 3. Distribution of Poaceae species richness in the grid squares used to divide the state of Coahuila.

Disakisperma dubium, Muhlenbergia tenuifolia, Panicum hallii, Setaria leucopila, and Tridentopsis mutica.

The 96 grass species restricted to a single grid square represent Coahuila it is rare elements. These species are found in only 28 squares and are considered irreplaceable for conservation (Figure 2), because they must be considered, if we want to assure the long-term survival of these grasses. The 28 irreplaceable grid squares record 313 out of the 316 species. The three species not recorded are: Aristida oligan-

Table 2. Number of native, rare, endemic, and introduced grasses in Coahuila.

\begin{tabular}{lcccc}
\hline Subfamily & Native & Rare & Endemic & Introduced \\
\hline Bambusoideae & -- & -- & - & 2 \\
Ehrhartoideae & 1 & -- & - & 1 \\
Pooideae & 65 & 15 & 5 & 21 \\
Panicoideae & 64 & 20 & - & 23 \\
Danthonioideae & 2 & 1 & - & - \\
Arundinoideae & -- & -- & - & 2 \\
Aristidoideae & 12 & -- & - & - \\
Chloridoideae & 109 & 22 & 2 & 16 \\
Total & 253 & 58 & 7 & 65 \\
\hline
\end{tabular}

Table 3. Grass species richness in 28 grid squares (Figure 1) or irreplaceable sites (with species exclusive to the grid) in Coahuila. Abbreviations of morphotectonic provinces are: ALTI = Altiplanense, $\mathrm{COAH}=$ Coahuilense, $\mathrm{SMOR}=$ Sierra Madre Orientalense, TAMA = Tamaulipense

\begin{tabular}{|c|c|c|c|}
\hline Grid square & $\begin{array}{c}\text { Total } \\
\text { species }\end{array}$ & $\begin{array}{c}\text { Exclusive } \\
\text { species }\end{array}$ & $\begin{array}{l}\text { Morphotectonic } \\
\text { province }\end{array}$ \\
\hline 7 & 31 & 4 & $\mathrm{COAH}$ \\
\hline 8 & 46 & 1 & $\mathrm{COAH}$ \\
\hline 15 & 56 & 2 & $\mathrm{COAH}$ \\
\hline 17 & 15 & 1 & $\mathrm{COAH}$ \\
\hline 20 & 12 & 2 & TAMA \\
\hline 25 & 36 & 2 & $\mathrm{COAH}$ \\
\hline 30 & 27 & 3 & TAMA \\
\hline 36 & 30 & 1 & $\mathrm{COAH}$ \\
\hline 45 & 27 & 1 & $\mathrm{COAH}$ \\
\hline 49 & 40 & 4 & $\mathrm{COAH}$ \\
\hline 67 & 42 & 1 & $\mathrm{COAH}$ \\
\hline 68 & 64 & 6 & $\mathrm{COAH}$ \\
\hline 69 & 17 & 1 & $\mathrm{COAH}$ \\
\hline 70 & 23 & 2 & $\mathrm{COAH}$ \\
\hline 78 & 36 & 7 & $\mathrm{COAH}$ \\
\hline 80 & 23 & 1 & $\mathrm{COAH}$ \\
\hline 84 & 10 & 1 & $\mathrm{COAH}$ \\
\hline 89 & 13 & 2 & $\mathrm{COAH}$ \\
\hline 95 & 46 & 1 & $\mathrm{COAH}$ \\
\hline 102 & 51 & 2 & $\mathrm{COAH}$ \\
\hline 104 & 21 & 1 & ALTI, COAH \\
\hline 106 & 18 & 1 & ALTI, COAH \\
\hline 107 & 21 & 2 & ALTI, COAH \\
\hline 109 & 38 & 2 & $\mathrm{COAH}$ \\
\hline 110 & 131 & 17 & $\mathrm{COAH}$ \\
\hline 111 & 143 & 14 & $\mathrm{COAH}, \mathrm{SMOR}$ \\
\hline 118 & 110 & 7 & $\mathrm{COAH}, \mathrm{SMOR}$ \\
\hline 119 & 118 & 7 & SMOR \\
\hline
\end{tabular}

tha, Paspalum urvillei, and Setariopsis auriculata. Table 3 summarizes the number of species recorded in each of the 28 squares, and also includes their position according to the morphotectonic provinces in Coahuila (Figure 1) (Ferrusquía-Villafranca, 1990). The Coahuilense province records the larger number of grid squares (20); the Tamaulipense province includes two (grid squares 20 and 30), one in the Sierra Madre Orientalense province (grid 119) and five additional grids combine territories between two adjoining provinces, as are the Altiplanense and Coahuilense provinces (grids 104, 106, and 107) or Coahuilense and Sierra Madre Orientalense (grids 111 and 118).

Table 4 summarizes the Poaceae richness recorded in the morphotectonic provinces occurring in Coahuila. The Coahuilense province has 281 species with 78 species known only from this province. The Sierra Madre Orientalense province contains 174 species with 17 unique species. The Tamaulipense province includes 90 species and ten of 
Table 4. Morphotectonic provinces in Coahuila and grass species richness. Between parentheses is the number of irreplaceable grid squares restricted to the selected province or shared with its neighbor province.

\begin{tabular}{cccc}
\hline $\begin{array}{c}\text { Morphotectonic } \\
\text { province }\end{array}$ & Species & $\begin{array}{c}\text { Exclusive } \\
\text { species }\end{array}$ & $\begin{array}{c}\text { Irreplaceable } \\
\text { grids }\end{array}$ \\
\hline ALTI & 56 & 2 & $3(3)$ \\
COAH & 281 & 78 & $24(5)$ \\
SMOR & 174 & 17 & $3(3)$ \\
TAMA & 90 & 10 & 2 \\
\hline
\end{tabular}

these are unique to the province. The Altiplanense province has 56 species and two unique species.

Since 28 grid squares identified are irreplaceable and contain $99 \%$ of the Poaceae richness, we carried out a complementary analysis of these 28 grid squares excluding the three unplaced species. Table 5 sorts the 28 grid squares containing most of the species in descending order; their distribution covers all the state's territory and their configuration could allow the establishment of corridors to facilitate species mobility among most of them. This strategy could guarantee the surviving of both, the species restricted to their territory as the other more widespread species. So the higher grids have diverse habitats worthy of preservation.

\section{Discussion}

The 319 Poaceae species recorded in Coahuila represent $10.5 \%$ of the total floristic richness reported by Villarreal (2001) for all plants; additionally, these 319 species represent $26.9 \%$ of the Poaceae richness in Mexico, and $2.5 \%$ (seven spp.) represent the country endemics (Dávila et al., 2006). Rzedowski (1975) considers that the high grass richness found in Mexico reflects the autochthonous origin of the flora, this pattern is also found in the state of Coahuila. The dominance of species in the Chloridoideae, mostly

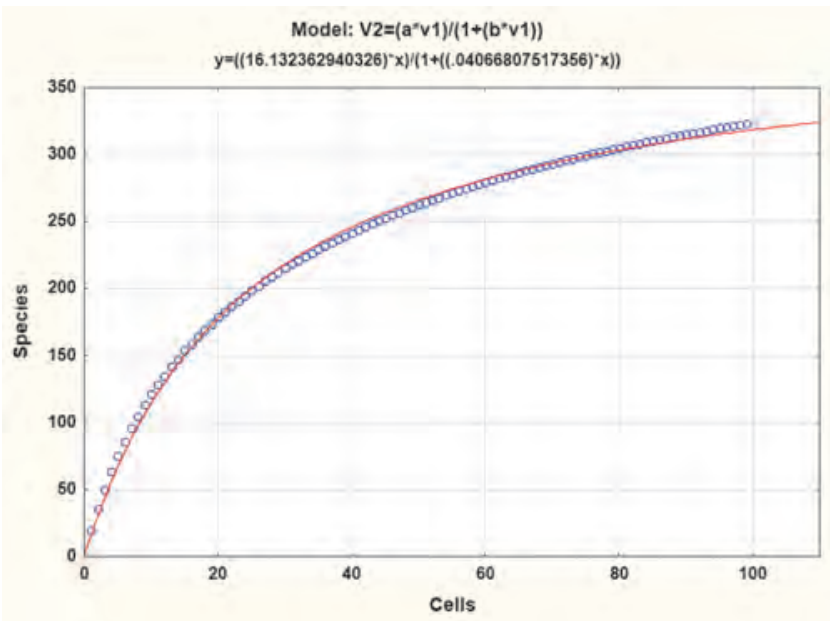

Figure 4. Species accumulation curve for Poaceae in the state of Coahuila. The curve's asymptot is reached at 396 species. found in arid and semi-arid environments, also corresponds with the dominant environment in the state (Valdés, 1977).

Areas with the highest species richness in Coahuila are also important collecting sites and have attracted notable botanical explorers such as Edward Palmer and Cyrus Pringle. The high rate of endemism is also related to this phenomenon, although other regions, such as Cuatro Ciénegas or the Sierra Maderas del Carmen, without strong historical records, are centers of endemism (Villarreal-Quintanilla and EncinaDomínguez, 2005).

The effort accumulation curve using Clench's function indicates a Poaceae richness of $81.5 \%$, pointing to an increase of 73 species (Koellner et al., 2004). Our results denote the need to increase the collecting effort in 23 grid squares (19\% of state's surface) where no grasses have been recorded (Figure 3). Surely their exploration will extend the known distribution of many species and add new records.

The Coahuilense morphotectonic province contains the greatest number of irreplaceable sites ( 24 grid squares with exclusive species), although four of them are shared with

Table 5. Hierarchical arrangement of grid squares selected to establish a conservation strategy for the grasses in Coahuila.

\begin{tabular}{|c|c|c|c|}
\hline Priority & Grid square & Complement & $\begin{array}{c}\% \text { species } \\
\text { accumulated }\end{array}$ \\
\hline 1 & 111 & 170 & 45.7 \\
\hline 2 & 110 & 117 & 62.6 \\
\hline 3 & 119 & 93 & 70.3 \\
\hline 4 & 118 & 81 & 74.1 \\
\hline 5 & 49 & 70 & 77.6 \\
\hline 6 & 7 & 60 & 80.8 \\
\hline 7 & 68 & 51 & 83.7 \\
\hline 8 & 25 & 43 & 86.3 \\
\hline 9 & 78 & 36 & 88.5 \\
\hline 10 & 15 & 32 & 89.8 \\
\hline 11 & 30 & 28 & 91.0 \\
\hline 12 & 109 & 25 & 92.0 \\
\hline 13 & 70 & 22 & 93.0 \\
\hline 14 & 67 & 20 & 93.6 \\
\hline 15 & 95 & 18 & 94.2 \\
\hline 16 & 102 & 16 & 94.9 \\
\hline 17 & 36 & 14 & 95.5 \\
\hline 18 & 107 & 12 & 96.2 \\
\hline 19 & 89 & 10 & 96.8 \\
\hline 20 & 20 & 8 & 97.4 \\
\hline 21 & 8 & 7 & 97.8 \\
\hline 22 & 45 & 6 & 98.1 \\
\hline 23 & 80 & 5 & 98.4 \\
\hline 24 & 106 & 4 & 98.7 \\
\hline 25 & 69 & 3 & 99.0 \\
\hline 26 & 17 & 2 & 99.4 \\
\hline 27 & 104 & 1 & 99.7 \\
\hline 28 & 84 & 0 & 100.0 \\
\hline
\end{tabular}


two neighbor provinces (Altiplanense and Sierra Madre Orientalense) because this offers many diverse habitats. The Altiplanense province has three irreplaceable sites and it is found in the southern part of the state $(112,113,114$, $115,116,117,120,121$, and 122). This province has higher grass richness further south in San Luis Potosí and Zacatecas, seen in the Asteraceae (Balleza and Villaseñor, 2011). In contrast, the Sierra Madre Orientalense province, which also finds its northernmost limit in the state (grid squares $111,115,116,117,118,119$, and 122) records three irreplaceable sites (grids 111, 118, and 119), sharing its foothills with the Coahuilense province.

The 28 irreplaceable grid squares include a surface of about $31,724 \mathrm{~km}^{2}$, representing a little more than $21 \%$ of the state's surface (Figure 2). Undoubtedly this area is too large to be considered in conservation strategies. However, its identification will allow the planning and further action, such as forming conservation refuges. These highly unique areas will be then inventoried for other plants and animals. In this way, we can contribute to the scientific knowledge and begin to initiate a list of possible areas to protect in the future.

The southeastern edge of the state where the Sierra Madre Orientalense morphotectonic province exists has the largest floristic richness. The three irreplaceable grid squares in this region have high richness values (Table 4). There are many diverse habitats in this region and it is located within the confluence of two provinces, these squares increase the biogeographical complexity and the environmental heterogeneity, which favor the occurrence of a large number of species. This region was identified as a biogeographic node for the Asteraceae (González-Zamora et al., 2007), where the nodes represent regions with biotic elements from different sources; i.e., from different geological origins and climatic regimes. All these factors combine to promote a high biodiversity and increased endemism (hotspots). This area is important because it contains a diverse assemblage of grasses and should be considered for conservations measures. Additional studies on the diversity and distribution of introduced and invasive species (Valdés, 2008) are needed to understand the impact of agricultural and forest practices. Our results emphasize the need for ongoing collecting activities in Coahuila, particularly of grasses and other organisms, especially in the already protected natural areas.

\section{Acknowledgments}

We thank the curators of the herbaria ANSM, MEXU, TEX, TAES, and US for their help during the review of material. Paul M. Peterson and Gabriel Sánchez-Ken reviewed the checklist of selected subfamilies. Paul and an anonymous reviewer made important additions that improved the manuscript. Celia Portillo of the University of Texas at Brownsville, careful review and made changes that im- proved the manuscript. Sergio G. Gómez helped with data base handling, collecting information, and georeferencing of specimens.

\section{Literature cited}

Balleza J.J. and Villaseñor J.L. 2011. Contribución del estado de Zacatecas (México) a la conservación de la riqueza florística del Desierto Chihuahuense. Acta Botanica Mexicana 94:61-89.

Bell H.L. Columbus J.T. and Ingram A.L. 2012. Kalinia, a new North American genus for a species long misplaced in Eragrostis (Poaceae, Chloridoideae). Aliso 30:85-95.

Colwell R.K. 2009. EstimateS Version 8.2.0: statistical estimation of species richness and shared species from samples (Software and User's Guide). Edited by himself, Storrs.

Colwell R.K. and Coddington J.A. 1994. Estimating terrestrial biodiversity through extrapolation. Philosophical Transactions of the Royal Society of London Series B 345:101-118.

Dávila A.P., Mejía-Saulés M.T., Gómez-Sánchez M., Valdés-Reyna J., Ortiz J.J., Morín C., Castrejón J. and Ocampo A. 2006. Catálogo de las Gramíneas de México. Universidad Nacional Autónoma de México, Comisión Nacional para el Conocimiento y Uso de la Biodiversidad, México, D.F.

ESRI. 2010. ArcGIS Desktop 10. Environmental Systems Research Institute, Redlands.

Ferrusquía-Villafranca I. 1990. Provincias bióticas (con énfasis en criterios morfotectónicos). Escala 1:4 000 000. In: Regionalización Biogeográfica, Atlas Nacional de México, vol. II, IV.8.10., Instituto de Geografía, Universidad Nacional Autónoma de México, México, D. F.

Finot V.L., Marticorena C., Barrera J.A., Muñóz-Schick M. and Negritto M.A. 2009. Diversidad de la familia Poaceae (Gramineae) en la región del Bío-Bío, Chile, basada en colecciones de herbario. Gayana Botánica 66:134-157.

González-Zamora A., Luna V.I., Villaseñor J.L. and Ruiz-Jiménez C.A. 2007. Distributional patterns and conservation of species of Asteraceae (asters etc.) endemic to eastern Mexico: a panbiogeographical approach. Systematics and Biodiversity 5:135144.

IUCN. International Union for Conservation of Nature. 2001. IUCN Red List Categories and Criteria: Version 3.1. $2^{\text {nd }}$ ed. International Union for Conservation of Nature, Gland.

Jiménez-Valverde A. and Hortal J. 2003. Las curvas de acumulación de especies y la necesidad de evaluar la calidad de los inventarios biológicos. Revista Ibérica de Aracnología 8:151161.

Klopper R.R., Gautier L., Chatelain C., Smith G.F. and Spichiger R. 2007. Floristics of the angiosperm flora of Sub-Saharan Africa: an analysis of the African plants checklist and database. Taxon 56:201-208.

Koellner T., Hersperger A.M. and Wohlgemuth T. 2004. Rarefaction method for assessing plant species diversity on a regional scale. Ecography 27:532-544.

Mittermeier R.A. 1988. Primate diversity and the tropical forest. In: Wilson E.O. Ed. Biodiversity, pp. 145-154, National Academic Press, Washington, D.C.

Moat J. 2007. Conservation assessment tools extension for ArcView 3.x, version 1.2. GIS Unit. Royal Botanic Gardens, Kew, London. 
The grass family (Poaceae) in Coahuila, Mexico: Diversity and distribution

Peterson P.M., Romaschenko K., Snow N. and Johnson G. 2012. A molecular phylogeny and classification of Leptochloa (Poaceae: Chloridoideae: Chlorideae) sensu lato and related genera. Annals of Botany 109:1317-1330.

Peterson P.M., Romaschenko K. and Herrera A.Y. 2014. A molecular phylogeny and classification of the Cteniinae, Farragininae, Gouiniinae, Gymnopogoninae, Perotidinae, and Trichoneurinae (Poaceae: Chloridoideae: Cynodonteae). Taxon 63:275-286.

Rzedowski J. 1975. An ecological and phytogeographycal analysis of the grasslands of México. Taxon 24:67-80.

Saarela J.M., Peterson P.M. and Valdés-Reyna J. 2014. A taxonomic revision of Bromus (Poaceae: Pooideae: Bromeae) in México and Central America. Phytotaxa 185:1-147

Smith G.F. and Wolfson M.M. 2004. Mainstreaming biodiversity: the role of taxonomy in bioregional planning activities in South Africa. Taxon 53:467-468.

Snow N., Peterson P.M., Romaschenko K. 2013. Systematics of Disakisperma (Poaceae, Chloridoideae, Chlorideae. PhytoKeys 26: $21-70$.

Soberón M.J. and Llorente B.J. 1993. The use of species accumulation functions for the prediction of species richness. Conservation Biology 7:480-488.

Suárez-Mota M.E. and Villaseñor J.L. 2011. Las Compuestas endémicas de Oaxaca, México: diversidad y distribución. Boletín de la Sociedad Botánica de México 88:55-61.

StatSoft Inc. 2011. STATISTICA (data analysis software system). Version 10.

Valdés R.J. 1977. Gramíneas de Coahuila. Lista de especies (con nombres y símbolos): clave para los géneros. Monografía Técnico Científica 3:884-1018.
Valdés R.J. 2008. Gramíneas Invasoras del noreste de México. Universidad Autónoma Agraria Antonio Narro. Base de datos. SNIB-CONABIO. Proyecto EK002. México D.F.

Valdés R.J. and Cabral I.I. 1993. Chorology of Mexican grasses. In: Ramamoorthy T.P., Bye R., Lot A. and Fa J. Eds. Biological Diversity of Mexico: Origins and Distribution, pp. 439-446, Oxford University Press, New York.

Valdés R.J. and Dávila A.P.D. 1995. Clasificación de los géneros de gramíneas (Poaceae) mexicanas. Acta Botanica Mexicana 33:37-50.

Valdés R.J. and Dávila A.P. 1998. Base de datos de las gramíneas (Poaceae) del noreste de México. Universidad Autónoma Agraria Antonio Narro. Informe final. SNIB-CONABIO. Proyecto No. G029. México, D.F.

Villarreal Q.J.Á. 2001. Flora de Coahuila. Listados florísticos de México 23:1-138.

Villarreal-Quintanilla J.Á. and Encina-Domínguez J.A. 2005. Plantas vasculares endémicas de Coahuila y algunas áreas adyacentes, México. Acta Botanica Mexicana 70:1-46.

Villaseñor J.L. 2003. Diversidad y distribución de las Magnoliophyta de México. Interciencia 28:160-167.

Villaseñor J.L. and Ortiz E. 2012. La familia Asteraceae en la flora del Bajío y de regiones adyacentes. Acta Botanica Mexicana 100:259-291.

Villaseñor J.L., Meave J.A., Ortiz E. and Ibarra-Manríquez G. 2003. Biogeografía y conservación de los bosques tropicales húmedos de México. Páginas 209-216. In: Morrone J.J. and Llorente B.J. Eds. Una Perspectiva Latinoamericana de la Biogeografía. Comisión Nacional para el Conocimiento y Uso de la Biodiversidad, Universidad Nacional Autónoma de México, La Prensa de Ciencias, Mexico City.

Received: February 28th, 2014

Accepted July 3rd, 2014 


\section{Jesús VALDÉs-Reyna ET AL.}

Appendix 1. List of species of Poaceae recorded in the state of Coahuila. $\left({ }^{*}\right)$ indicates endemic to the states, $\left({ }^{x}\right)$ exotic or introduced species, and $\left(^{+}\right)$rare species. The list includes subspecific taxa although they were not used in the analysis.

\begin{tabular}{|c|c|}
\hline Achnatherum editorum (E.Fourn.) Valdés-Reyna \& Barkworth & ×Bothriochloa hirtifolia (J.Presl) Henrard \\
\hline Achnatherum eminens (Cav.) Barkworth & ${ }^{\times}$Bothriochloa ischaemum (L.) Keng var. songarica (Rupr. ex \\
\hline Achnatherum hirticulme (S.L.Hatch, Valdés-Reyna \& Morden) & Fisch. \& Meyen) Celerier \& J.R.Harlam \\
\hline Valdés-Reyna \& Barkworth & Bothriochloa laguroides (DC.) Herter subsp. torreyana \\
\hline Achnatherum lobatum (Swallen) Barkworth & (Steud.) Allred \& Gould \\
\hline $\begin{array}{l}\text { Achnatherum multinode (Scribn. ex Beal) Valdés-Reyna \& } \\
\text { Barkworth }\end{array}$ & $\begin{array}{l}\text { Bothriochloa saccharoides (Sw.) Rydb. subsp. reevesii (Gould) } \\
\text { Allred \& Gould }\end{array}$ \\
\hline Achnatherum robustum (Vasey) Barkworth & +Bothriochloa springfieldii (Gould) L.R.Parodi \\
\hline Agrostis hyemalis (Walter) Britton, Sterns \& Poggenb. & Bouteloua aristidoides (Kunth) Griseb. \\
\hline${ }^{+}$Allolepis texana (Vasey) Sodestrom \& Decker & Bouteloua barbata Lag. \\
\hline Amelichloa clandestina (Hack.) Arriaga \& Barkworth & Bouteloua chasei Swallen \\
\hline Andropogon gerardii Vitman & Bouteloua chondrosioides (Kunth) Benth.ex Watson \\
\hline $\begin{array}{l}\text { Andropogon glomeratus (Walter) Britton, Sterns \& Poggenb. } \\
\text { Aristida adscensionis L. }\end{array}$ & $\begin{array}{l}\text { Bouteloua curtipendula (Michx.)Torr. var. caespitosa Gould \& } \\
\text { Kapadia }\end{array}$ \\
\hline Aristida arizonica Vasey & Bouteloua curtipendula (Michx.)Torr. var. curtipendula \\
\hline Aristida curvifolia E.Fourn. & +Bouteloua curtipendula (Michx.) Torr. var. tenuis Gould \& \\
\hline Aristida divaricata Humb. \& Bonpl. ex Willd. & Kapadia \\
\hline Aristida eludens Allred \& Valdés-Reyna & Bouteloua dactyloides (Nutt.) Columbus \\
\hline Aristida gypsophyla Beetle fo. gypsophyla & +Bouteloua erecta (Vasey \& Hack.) Columbus \\
\hline Aristida gypsophyla Beetle fo. gypsophyloides Allred \& & Bouteloua eriopoda (Torr.) Torr. \\
\hline Valdés-Reyna & *Bouteloua eriostachya (Swallen) J.Reeder \\
\hline Aristida havardii Vasey & Bouteloua gracilis (Willd. ex Kunth) Lag. ex Steud. \\
\hline Aristida oligantha Michx. & Bouteloua hirsuta Lag. \\
\hline Aristida pansa Wooton \& Standl. fo. contracta Allred \& & *Bouteloua johnstonii Swallen \\
\hline Valdés-Reyna & Bouteloua karwinskii (E.Fourn.) Griffiths \\
\hline Aristida pansa Wooton \& Standl. fo. dissita (I. M. Johnston) & +Bouteloua parryi (E.Fourn.) Griffiths \\
\hline Allred \& Valdés-Reyna & Bouteloua radicosa (E.Fourn.) Griffiths \\
\hline Aristida pansa Wooton \& Standl. fo. pansa & Bouteloua ramosa Scribn. ex Vasey \\
\hline $\begin{array}{l}\text { Aristida purpurea Nutt. fo. brownii (Warnock) Allred \& } \\
\text { Valdés-Reyna }\end{array}$ & $\begin{array}{l}\text { Bouteloua repens (Kunth) Scribn. \& Merr. } \\
\text { Bouteloua simplex Lag. }\end{array}$ \\
\hline Aristida purpurea Nutt. var. fendleriana (Steud.) Vasey & Bouteloua trifida S.Watson \\
\hline Aristida purpurea Nutt. var. Iongiseta (Steud.) Vasey & Bouteloua uniflora Vasey var. coahuilensis Gould \& Kapadia \\
\hline Aristida purpurea Nutt. var. nealleyi (Vasey) Allred & Bouteloua uniflora Vasey var. uniflora \\
\hline Aristida purpurea Nutt. var. perplexa Allred \& Valdés-Reyna & +Bouteloua warnockii Gould \& Kapadia \\
\hline Aristida purpurea Nutt. var. purpurea & Brachypodium mexicanum (Roem \& Schult.) Link. var. \\
\hline Aristida purpurea Nutt. var. wrightii (Nash) Allred & inerme Beetle \\
\hline $\begin{array}{l}\text { Aristida schiedeana Trin. \& Rupr. var. orcuttiana (Vasey) } \\
\text { Allred \& Valdés-Reyna }\end{array}$ & $\begin{array}{l}\text { Brachypodium mexicanum (Roem \& Schult.) Link. var. } \\
\text { mexicanum }\end{array}$ \\
\hline Aristida schiedeana Trin. \& Rupr. var. schiedeana & +Brachypodium pringlei Scribn. ex Beal \\
\hline Aristida ternipes Cav. var. gentilis (Henrard) Allred & Bromus anomalus Rupr. ex E. Fourn. \\
\hline Aristida ternipes Cav. var. ternipes & Bromus carinatus Hook. \& Arn. \\
\hline ×Arundo donax L. & ×Bromus catharticus Vahl. \\
\hline ×Avena fatua $\mathrm{L}$ & *Bromus densus Swallen \\
\hline ×Avena sativa (L.) Husskn. & Bromus frondosus (Shear) Wooton \& Standl. \\
\hline ×Bambusa vulgaris Schrad. ex J.C.Wendl. & ×Bromus inermis Leyss. \\
\hline +Blepharidachne bigelovii (S.Watson) Hack. & Bromus lanatipes (Shear) Rydb. \\
\hline Bothriochloa alta (Hitchc.) Henr. & Bromus richardsonii Link \\
\hline Bothriochloa barbinodis (Lag.) Herter var. barbinodis & ×Bromus tectorum $\mathrm{L}$. \\
\hline $\begin{array}{l}\text { Bothriochloa barbinodis (Lag.) Herter var. perforata (Trin. ex } \\
\text { Fourn.) Gould }\end{array}$ & $\begin{array}{l}\text { *Calamagrostis coahuilensis P.M.Peterson, Soreng \& } \\
\text { Valdés-Reyna }\end{array}$ \\
\hline
\end{tabular}


The grass family (Poaceae) in Coahuila, Mexico: Diversity and distribution

Appendix 1. Continuation.

Chascolytrum subaristatum (Lam.) Desv

${ }^{\times}$Cenchrus ciliaris L.

Cenchrus echinatus L.

${ }^{+}$Cenchrus myosuroides Kunth

Cenchrus setaceus (Forssk.) Morrone

Cenchrus spinifex Cav.

Cenchrus villosus (Spreng.) Spreng.

Chloris andropogonoides E.Fourn.

Chloris ciliata Sw.

Chloris cucullata Bisch.

${ }^{x}$ Chloris gayana Kunth

Chloris submutica Kunth

Chloris virgata Sw.

${ }^{\times}$Coix lacrima-jobi $\mathrm{L}$.

Cortaderia selloana (Schult. \& Schult. f.) Asch. \& Graebn.

${ }^{+}$Cottea pappophoroides Kunth

${ }^{\times}$Cymbopogon citratus (DC.) Stapf

${ }^{\times}$Cynodon dactylon (L.) Pers.

${ }^{\times}$Dactylis glomerata L.

×Dactyloctenium aegyptium (L.) Willd.

+Danthonia spicata (L.) P.Beauv. ex Roem. \& Schult.

Dasyochloa pulchella (Kunth) Willd.ex Rydb.

Deschampsia caespitosa (L.) P.Beauv.

Dichanthelium acuminatum (Sw.) Gould \& C.A.Clark var. acuminatum

Dichanthelium acuminatum (Sw.) Gould \& C.A.Clark var. lindheimeri (Nash) Gould \& C.A.Clark

Dichanthelium acuminatum (Sw.) Gould \& C.A.Clark var. longiligulatum (Nash) Gould \& C.A.Clark

Dichanthelium oligosanthes (Schult.) Gould var. scribnerianum (Nash) Fernld

Dichanthelium pedicellatum (Vasey) Gould

×Dichanthium annulatum (Forssk.) Stapf

${ }^{\star}$ Dichanthium aristatum (Poir.) C.E. Hubb.

Digitaria californica (Benth.) Henrard

Digitaria ciliaris (Retz.) Koeler

+Digitaria hitchcockii (Chase) Stuck.

Digitaria insularis (L.) Fedde

${ }^{\times}$Digitaria ischaemum (Schreb.) Muhl.

Digitaria pubiflora (Vasey) Wipff

${ }^{\times}$Digitaria sanguinalis (L.) Scop.

Diplachne fusca (L.) P. Beauv. ex Roem. \& Schult. subsp. fascicularis (Lam.) P.M.Peterson \& N.Snow

Dinebra panicea (Retz.) Ohwi subsp. mucronata (Michx.) P.M.Peterson \& N.Snow

Disakisperma dubium (Kunth) P.M.Peterson \& N.Snow

Distichlis littoralis (Engelm.) H.L.Bell \& Columbus

Distichlis spicata (L.) Greene

${ }^{x}$ Echinochloa colona (L.) Link

${ }^{x}$ Echinochloa crus-gallii (L.) P.Beauv.

${ }^{+}$Echinochloa crus-pavonis (Kunth) Schult.
Echinochloa muricata (P.Beauv.) Fernard

${ }^{x}$ Eleusine indica (L.) Gaertn.

${ }^{x}$ Eleusine multiflora Hochst. ex A.Rich.

Elymus arizonicus (Scribn. \& J.G.Sm.) Gould

Elymus canadensis L.

Elymus elymoides (Raf.) Swezey

xElymus repens (L.) Gould

Elymus trachycaulus (Link) Gould ex Shinners

Enneapogon desvauxii P.Beauv.

${ }^{\star}$ Eragrostis barrelieri Daveau

${ }^{x}$ Eragrostis cilianensis (All.) Vignolo ex Janch.

${ }^{x}$ Eragrostis ciliaris (L.) R.Br.

+Eragrostis curtipedicellata Buckley

×Eragrostis curvula (Schrad.) Nees

Eragrostis erosa Scribn. ex Beal

Eragrostis hypnoides (Lam.) B.S.P.

Eragrostis intermedia Hitchc.

×Eragrostis lehmanniana Nees

Eragrostis lugens Nees

Eragrostis mexicana (Hornem.) Link

Eragrostis palmeri S.Watson

Eragrostis pectinacea (Michx.) Nees var. miserrima (Fourn.)

Reeder

Eragrostis pectinacea (Michx.) Nees var. pectinacea

${ }^{x}$ Eragrostis pilosa (L.) P.Beauv.

Eragrostis reptans (Michx.) Nees

Eragrostis spectabilis (Pursh) Steud.

×Eragrostis superba Peyr.

Eriochloa acuminata (J. Presl) Kunth var. acuminata

Eriochloa acuminata (J. Presl) Kunth var. minor (Vasey)

R.B.Shaw

+Eriochloa punctata (L.) Desv. ex Hamilt.

${ }^{+}$Eriochloa sericea (Scheele) Munro ex Vasey

Erioneuron avenaceum (Kunth) Tateoka

Erioneuron nealleyi (Vasey) Tateoka

Erioneuron pilosum (Buckley) Nash

Festuca arizonica Vasey

*Festuca coahuilana Gonz.-Led. \& S.D.Koch

+Festuca ligulata Swallen

+Festuca pinetorum Swallen

Festuca rubra L.

Festuca thurberi Vasey

*Festuca valdesii Gonz.-Led. \& S.D.Koch

Glyceria striata (Lam.) Hitchc.

×Hemarthria altissima (Poir.) Stapf. \& C.E.Hubb.

Hesperostipa neomexicana (Thurb.) Barkworth

Heteropogon contortus (L.) P.Beauv. ex Roem. \& Schult.

Hilaria belangeri (Steud.) Nash

Hilaria swallenii Cory

Hopia obtusa (Kunth) Zuloaga \& Morrone

Hordeum jubatum L. 
Appendix 1. Continuation.

${ }^{x}$ Hordeum murinum (Kunth) Zuloaga \& Morrone

${ }^{\times}$Hordeum vulgare $\mathrm{L}$.

Jarava ichu Ruiz \& Pav.

${ }^{+}$Kalinia obtusiflora (E.Fourn.) H.L. Bell \& Columbus

Koeleria macrantha (Ledeb.) Schult.

Leersia hexandra Sw.

+Leersia monandra Sw.

Leptochloa crinita (Lag.) P.M.Peterson \& N.Snow

Leptochloa pluriflora (E.Fourn.) P.M.Peterson \& N.Snow

Leymus condensatus (J.Presl) Á. Löve

+Limnodea arkansana (Nutt.) L.H.Dewey

+Lolium multiflorum Lam.

+Lolium perenne L. var. aristatum Schard.

+Melica montezumae Piper

+Melica nitens (Scribn.) Nutt. ex Piper

${ }^{+}$Melica porteri Scribn.

×Melinis repens (Willd.) Zizka

Metcalfia mexicana (Scribn.) Conert

${ }^{+}$Microchloa kunthii Desv.

Muhlenbergia alopecuroides (Griseb.) P.M.Peterson \&

Columbus

Muhlenbergia arenacea (Buckley) Hitchc.

Muhlenbergia arenicola Buckley

${ }^{+}$Muhlenbergia asperifolia (Nees \& Meyen ex Trin.) Parodi

+Muhlenbergia depauperata Scribn.

Muhlenbergia dubia E.Fourn.

Muhlenbergia emersleyi Vasey

Muhlenbergia glauca (Nees) B.D.Jacks.

Muhlenbergia gypsophila Reeder \& C.Reeder

Muhlenbergia lindheimeri Hitchc.

${ }^{+}$Muhlenbergia macroura (Kunth) Hitchc.

Muhlenbergia microsperma (DC.) Kunth

${ }^{+}$Muhlenbergia montana (Nutt.) Hitchc.

Muhlenbergia phleoides (Kunth) Columbus

Muhlenbergia polycaulis Scribn.

Muhlenbergia porteri Scribn. ex Beal

Muhlenbergia pubigluma Swallen

Muhlenbergia quadridentata (Kunth) Trin.

${ }^{+}$Muhlenbergia racemosa (Michx.) Britton Sterns \& Poggenb.

Muhlenbergia ramulosa (Kunth) Swallen

Muhlenbergia repens (J.Presl) Hitchc.

Muhlenbergia rigens (Benth.)Hitchc.

Muhlenbergia rigida (Kunth) Kunth

${ }^{+}$Muhlenbergia robusta (E.Fourn.) Hitchc.

Muhlenbergia setifolia Vasey

Muhlenbergia spiciformis Trin.

Muhlenbergia tenuifolia (Kunth) Kunth

+Muhlenbergia torreyi (Kunth) Hitchc. ex Bush

Muhlenbergia tricholepis (Torr.) Columbus

Muhlenbergia utilis (Torr.)Hitchc.

Muhlenbergia villiflora Hitchc.var. villosa (Swallen) Morden
${ }^{+}$Muhlenbergia wrightii Vasey ex J.M.Coult.

Nassella leucotricha (Trin. \& Rupr.) R.W.Pohl

Nassella mucronata (Kunth) P.W. ohl

Nassella tenuissima (Trin.) Barkworth

Oplismenus hirtellus (L.) P.Beauv. subsp. hirtellus

Oplismenus hirtellus (L.) P.Beauv. subsp. setarius (Lam.)

Mez ex. Ekman

Panicum alatum Zuloaga \& Morrone

×Panicum antidotale Retz.

+Panicum capillare L.

xPanicum coloratum L.

+Panicum decolorans Kunth

+Panicum hallii Vasey var. filipes (Scribn.) F.R.Waller

Panicum hallii Vasey var. hallii

+Panicum hirticaule Presl.

+Panicum lepidulum Hitchc. \& Chase

+Panicum parcum Hitchc. \& Chase

+Panicum rigidulum Bosc. ex Nees.

+Panicum virgatum $\mathrm{L}$.

Pappophorum bicolor E. Fourn.

×Pappophorum pappiferum (Lam.) Kuntze

Pappophorum vaginatum Buckley

Pascopyrum smithii (Rydb.) Barkworth \& D.R.Dewey

+Paspalum crinitum Chase

×Paspalum denticulatum Trin.

+Paspalum dilatatum Poir.

Paspalum distichum L.

Paspalum pubiflorum Rupr. ex E.Fourn.

Paspalum setaceum Michx. var. ciliatifolium (Michx.) Vasey

×Paspalum urvillei Steud.

Peyritschia deyeuxioides (Kunth) Finot

×Phalaris canariensis $\mathrm{L}$.

Phalaris caroliniana Walt.

×Phalaris minor Retz.

+Phleum alpinum $\mathrm{L}$.

×Phragmites australis (Cav.) Trin. ex Steud.

×Phyllostachys aurea Carrière ex Rivière \& C.Rivière

+Piptochaetium angustifolium (Hitchc.) Valencia \& Costas

Piptochaetium fimbriatum (Kunth) Hitchc.

Piptochaetium pringlei (Beal) Parodi

+Piptochaetium virescens (Kunth) Parodi

Pleuraphis mutica Buckley

×Poa annua L.

Poa bigelovii Vasey \& Scribn.

×Poa compressa L.

Poa fendleriana (Steud.) Vasey

+Poa occidentalis (Vasey) Vasey

Poa palmeri Soreng \& P.M.Peterson

×Poa pratensis L. subsp. agassiezensis (B.Boivin \& D.Löve)

Roy L.Taylor \& MacBryde

+Poa ruprechtii Peyr. 
The grass family (Poaceae) in Coahuila, Mexico: Diversity and distribution

Appendix 1. Continuation.

Poa strictiramea Hitchc.

*Poa wendtii Soreng \& P.M.Peterson

Polypogon elongatus Kunth

xPolypogon monspeliensis (L.) Desf.

xPolypogon viridis (Gouan) Breistr.

${ }^{\times}$Schedonorus arundinaceus (Schreb.) Dumort.

Schizachyrium cirratum (Hack.)Wooton \& Standl.

Schizachyrium sanguineum (Retz.) Alston

Schizachyrium scoparium (Michx.) Nash

Scleropogon brevifolius Phil.

${ }^{x}$ Secale cereale L.

×Setaria adhaerens (Forssk.) Chiov.

Setaria grisebachii E.Fourn.

Setaria leucopila (Scribn. \& Merr.) K.Schum.

Setaria macrostachya Kunth

+ Setaria magna Griseb.

×Setaria parviflora (Poir.) Kerguélen

Setaria pumila (Poir.) Roem. \& Schult.

Setaria reverchonii (Vasey) Pilg. var. ramiseta (Scribn.)

\section{W.E.Fox}

Setaria reverchonii (Vasey) Pilg. var. reverchonii

Setaria scheelei (Steud.) Hitchc.

×Setaria verticillata (L.) P. Beauv.

${ }^{+}$Setaria villosissima (Scribn. \& Merr.) K.Schum.

+ Setariopsis auriculata (E.Fourn.) Scribn.

+Sorghastrum brunneum Swallen

Sorghastrum nutans (L.) Nash

×Sorghum bicolor (L.) Moench.

×Sorghum halepense (L.) Pers.

+ Spartina spartinae (Trin.) Merr.ex Hitchc.

Sphenopholis obtusata (Michx.)Scribn.

Sporobolus airoides (Torr.)Torr. subsp. airoides

Sporobolus airoides (Torr.)Torr. subsp. regis (I.M. Johnston)

Wipff \& S.D.Jones

Sporobolus atrovirens (Kunth) Kunth
+Sporobolus coahuilensis Valdés-Reyna

+Sporobolus compositus (Poir.) Merr.

Sporobolus contractus Hitchc.

Sporobolus cryptandrus (Torr.) A.Gray

Sporobolus flexuosus (Thurb. ex Vasey) Rydb.

Sporobolus giganteus Nash

×Sporobolus indicus (L.) R.Br.

Sporobolus nealleyi Vasey

Sporobolus pyramidatus (Lam.) Hitchc.

Sporobolus spiciformis Swallen

Sporobolus wrightii Munro.

${ }^{\times}$Stenotaphrum secundatum (Walter) Kuntze

×Tragus berteronianus Schult.

Tridens albescens (Vasey) Woot \& Standl.

+Tridens flavus (L.) Hitchc.

Tridens texanus (S.Watson) Nash

+Tridentopsis eragrostoides (Vasey \& Scribn.) P.M.Peterson

Tridentopsis mutica (Torr.) P.M.Peterson

Tripsacum dactyloides (L.) L.

+Trisetum filifolium Scribn. ex Beal

+Trisetum palmeri Hitchc.

Trisetum spicatum (L.) K. Ritcht.

+Trisetum viride (Kunth) Kunth

'Triticosecale Wittm.

×Triticum aestivum $\mathrm{L}$.

+Urochloa arizonica (Scribn. \& Merr.) Morrone \& Zuloaga

Urochloa fusca (Sw.) B.F.Hansen \& Wunderlin

Urochloa meziana (Hitchc.) Morrone \& Zuloaga

Urochloa ophryodes (Chase) Morrone \& Zuloaga

×Urochloa plantaginea (Link) R.D.Webster

Urochloa texana (Buckley) R.D.Webster

Zea mays L.

×Zoysia matrella (L.) Merr. var. pacifica Goudswaard

Zuloagaea bulbosa (Kunth) Bess 